\title{
Analisis PGA (Peak Ground Acceleration) Pulau Lombok menggunakan Metode Pendekatan Empiris
}

\author{
Baiq Nora Kusumawardani, Lalu A. Didik*, dan Bahtiar \\ Program Studi Tadris Fisika, Fakultas Tarbiyah dan Keguruan Universitas Islam Negeri Mataram \\ Jln. Gajah Mada no.100, Jempong Mataram, Kota Mataram 83124, Lombok
}

\begin{abstract}
Intisari
Pulau Lombok berada di antara dua lempeng besar yaitu lempeng Asia dan lempeng Australia sehingga Pulau Lombok sangat rawan terhadap guncangan gempa bumi dan pergeseran tanah. Faktor yang mempengaruhi nilai percepatan tanah maksimum yaitu kondisi geologi dan karakteristik wilayah tersebut. Penelitian ini dilakukan untuk menganalisis nilai percepatan tanah maksimum menggunakan rumus empiris Donovan, Guirre, dan Mickey di Pulau Lombok dengan data sekunder gempa bumi Lombok dari Juli September 2018. Hasil analisis menunjukkan bahwa nilai percepatan tanah maksimum paling tinggi sebesar 0,11191 gal yang terjadi di daerah Lombok Utara yang setelah kejadian gempa termasuk kategori mengalami kerusakan berat. Nilai percepatan tanah maksimum terkecil terjadi didearah Lombok Tengah dengan besar 0,03441 gal dan termasuk kategori sangat ringan. Dari ketiga rumusan, yang mendekati nilai percepatan tanah maksimum berdasarkan peta Shakemap yaitu rumusan Guirre.
\end{abstract}

\begin{abstract}
Lombok Island is located between two large plates namely the Asian plate and the Australian plate so that Lombok Island is very prone to earthquake shocks and land shifts. Factors that influence the maximum land acceleration are geological conditions and characteristics of the region. This study aims to analyze the value of maximum soil acceleration using the empirical formula Donovan, Mc. Guirre, and M. V. Mickey on Lombok Island. The data used are secondary data from the Lombok earthquake from July to September 2018 and analyzed using the formulations of Donovan, Guirre, and Mickey. The results of the analysis showed that the highest maximum ground acceleration value of 0.11191 gal occurred in the area of North Lombok, and the area of North Lombok was included in the category of severely damaged. The smallest maximum land acceleration value occurred in Central Lombok with a large $0.03441 \mathrm{gal}$ and included in the very light category. Of the three formulations, which approaches the maximum land acceleration value based on the Shakemap map, is the Guirre formula.
\end{abstract}

Keywords: earthquake; empirical approach; maximum ground acceleration.

*Corresponding author: laludidik@uinmataram.ac,id

http://dx.doi.org/10.12962/j24604682.v16i3.6372

2460-4682 @Departemen Fisika, FSAD-ITS

\section{PENDAHULUAN}

Secara fisiografi Pulau Lombok termasuk ke dalam gunung api Nusa Tenggara yang merupakan salah satu dari bagian Busur Sunda. Satuan batuan Pulau Lombok terdiri atas batuan gunung api, sedimen, serta batuan trobosan yang memiliki umur berkisar dari tersier hingga dengan kuarter. Sehingga secara geologi Pulau Lombok terdapat sesar mendatar dan sesar normal dengan arah barat laut tenggara [1].

Lempeng samudera yang memiliki rapat massa lebih besar ketika bertumbukkan dengan lempeng benua yang berada dizona tumbukan (subduksi) dan akan menyusup ke bawah. Gerakan lempeng tersebut akan mengalami suatu perlambatan akibat dari gesekan selubung bumi tersebut. Perlambatan gerakan ini dapat menyebabkan penumpukkan energi di antara zona subduksi dan zona patahan. Akibat dari penumpukkan energi di zona-zona patahan tersebut ialah terjadinya suatu tekanan, tarikan dan geseran. Disaat batas elastisitas batuan tersebut terlampaui, maka akan terjadi suatu patahan batuan dan melepaskan energi secara tiba-tiba. Pada proses ini timbul getaran partikel ke segala arah yang biasa disebut dengan gelombang gempa bumi [2].

Akhir bulan Juli, wilayah Pulau Lombok mengalami berbagai rentetan kejadian gempa bumi yang diawali pada tanggal 29 Juli 2018 dengan kekuatan 6,4 SR yang disebut sebagai foreshock, 05 Agustus 2018 kekuatan 7,0 SR yang disebut sebagai mainshock pertama, 09 Agustus 2018 dengan $M$ 6,2 SR disebut sebagai aftershock signifikan, pada 19 Agustus 2018 yang didahului dengan foreshock kekuatannya sebesar 6,3 SR dan sepuluh jam setelahnya gempa berkekuatan 6,9 SR yang disebut sebagai mainshock kedua. Pulau Lombok, Nusa Tenggara Barat (NTB) terletak di kawasan tektonik yang aktif, 
yang mana beberapa sumber gempa bumi mengelilingi $\mathrm{Pu}-$ lau Lombok yang diantaranya yaitu Zona Back Arc Thrust di bagian utara, Megathrust bagian selatan, dan dibagian barat dan timur ada sistem sesar geser [3].

Gempabumi bisa terjadi apabila energi yang berada didalam bumi dikeluarkan dengan tiba-tiba yang mengakibatkan guncangan di permukaan tanah dalam bentuk tegangan pada batuan. Akibat dari pelepasan energi yang tersimpan dapat mengakibatkan deformasi yang ada pada lempeng tektonik di kerak bumi, energi inilah yang merambat ke permukaan yang dibawa oleh gelombang gempa tersebut. Gempabumi ini memiliki dampak pada pergerakan tanah, dan apabila semakin dekat suatu wilayah dengan pusat gempa maka akan mengakibatkan kerusakan yang besar terjadi di wilayah tersebut, tetapi kerusakan akan terjadi di suatu wilayah bergantung pada kondisi geologi wilayah setempat beserta dengan intensitas maksimum yang dimiliki [4].

Intensitas gempa bumi yaitu tingkat kerusakan yang terasa dilokasi terjadinya gempa bumi. Untuk angkanya sendiri ditentukan dengan menilai kerusakan yang dihasilkan, pengaruh pada benda-benda, bangunan, tanah, serta akibat pada orangorang sekitar. Skala atau kekuatan gempa ini disebut dengan MMI (Modified Mercalli Intensity) diperkirakan oleh Mercalli pada tahun 1902. Magnitude merupakan parameter yang diukur berdasarkan dengan kekuatan gempa yang terjadi pada wilayah tersebut, yang diakibatkan oleh guncangan gempa disumbernya. Selain itu, Charles F. Richter pada tahun 1934 mengusulkan skala Ritcher untuk mengklasifikasikan skala gempa bumi menjadi tiga bagian yakni: skala 1-3 skala richter sebagai gempa kecil, kemudian 4-6 skala richter desebut dengan gempa sedang, serta $>6$ skala richter disebutkan sebagai gempa yang kuat [5].

Kerusakan yang terjadi karena gempa bumi ditentukan oleh parameter-parameter gempa menggunakan metode pendekatan Peak Ground Accelaration (PGA) yang biasa disebut dengan nilai percepatan tanah maksimum. Nilai PGA dapat dihitung berdasarkan magnitudo dan jarak sumber gempa yang terjadi pada titik pengukuran [6]. PGA dapat ditentukan menggunakan dua cara yaitu pengukuran menggunakan alat accelerograph atau menggunakan pendekatan empiris. Peralatan accelerograph ini ditempatkan pada daerahdaerah yang fungsinya untuk mengukur berbagai variasi dari guncangan pada struktur geologi setempat. Dari hasil rekaman tersebut dapat memberikan informasi mengenai nilai percepatan tanah maksimum diwilayah tersebut baik guncangan yang sangat kuat maupun guncangan yang lemah dan informasi ini dapat dijadikan untuk memahami karakteristik getaran gempa. Accelerograph memiliki cara kerja yaitu getaran seismik yang berupa besaran fisis akan ditangkap oleh sensor yang memiliki fungsi untuk merubah besaran fisis itu menjadi besaran elektrik. Tegangan output dari accelrograph sudah berupa tegangan analog, ini yang kemudian akan dirubah oleh ADC menjadi count berbentuk digital [7].

Parameter guncangan maksimum tanah dapat dipengaruhi oleh tiga hal yaitu: ray path (jalur penjalaran gelombang dan hiposenter), sumber gempa (magnitudo, jenis-jenis sesarnya, serta yang berkaitan dengan sumber gempa bumi), dan yang ketiga yaitu dari faktor lokal yang bisa saja berupa keadaan wilayah seperti keadaan geologi atau karakteristik dari wilayah tersebut. Untuk bisa mendapatkan nilai PGA pada umumnya yaitu dari hasil observasi rekaman akselerograf, namun kekurangan dari akselerograf tidak tersebar secara merata di seluruh wilayah indonesia [8].

Secara umum gambaran untuk percepatan tanah maksimum yang sesuai dengan titik-titik yang dibutuhkan bisa dengan menggunakan pendekatan empiris. Pendekatan empiris lebih banyak digunakan karena adanya keterbatasan peralatan jaringan accelerograph. Pendekatan empiris yaitu metode yang digunakan untuk menghitung percepatan tanah yang dibuat oleh para ahli, metode empiris ini bagian dari relasi magnitudo dengan jarak. Dalam penentuan percepatan tanah maksimum ada beberapa rumusan empiris yang sering digunakan diantaranya yaitu metode Donovan [8], Guirre [8], Mickey [8], Fukushima-Tanaka [6], Estevan [6] MurphyObrein, Si dan Midorikawa [19]. Namun dalam makalah ini PGA dihitung menggunakan tiga metode yaitu metode Donovan, Guirre, dan Mickey. Ketiga metode tersebut digunakan karena memiliki persamaan yang dapat diaplikasikan pada kawasan Nusa Tenggara [9]. Oleh karena penelitian ini bertujuan untuk menganalisis nilai percepatan tanah maksimum menggunakan rumus empiris Donovan, Guirre dan Mickey di Pulau Lombok yang diakibatkan oleh gempa bumi tahun 2018.

\section{METODE PENELITIAN}

Penelitian dilaksanakan pada bulan September - Oktober 2019 di Badan Meteorologi Klimatologi dan Geofisika (BMKG) Selaparang. Metode yang digunakan adalah metode empiris Donovan, Guirre, dan Mickey, dalam menganalisis percepatan tanah maksimum di Pulau Lombok.

Data yang digunakan dalam penelitian ini adalah data gempa bumi pada bulan Juli September 2018 dari Badan Meteorologi Klimatologi dan Geofisika (BMKG) di Selaparang. Data yang dibutuhkan adalah waktu kejadian gempa bumi, hypocenter, dan magnitude. Proses pengolahan data menggunakan software ArcGis 10.3.

Perhitungan PGA dilakukan menggunakan persamaan empiris Donovan, Guirre dan Mickey yang secara berurutan dapat ditulis dalam Pers.(1)-(3) berikut: $[8,10]$

$$
\begin{aligned}
\alpha & =\frac{1080 \times 10^{0,5 M}}{(R+25)^{1,32}} \\
\alpha & =\frac{472,3 \times 10^{0,278 M}}{(R+25)^{-1,301}} \\
\alpha & =\frac{0,304 \times 10^{0,74 M}}{(R)^{\frac{-1}{4}}}
\end{aligned}
$$

dengan $\alpha$ mendeskripsikan percepatan tanah maksimum (gal), $M$ mengindikasikan magnitudo gelombang permukaan (M), dan $R$ menotasikan jarak hiposenter $(\mathrm{km})$. 

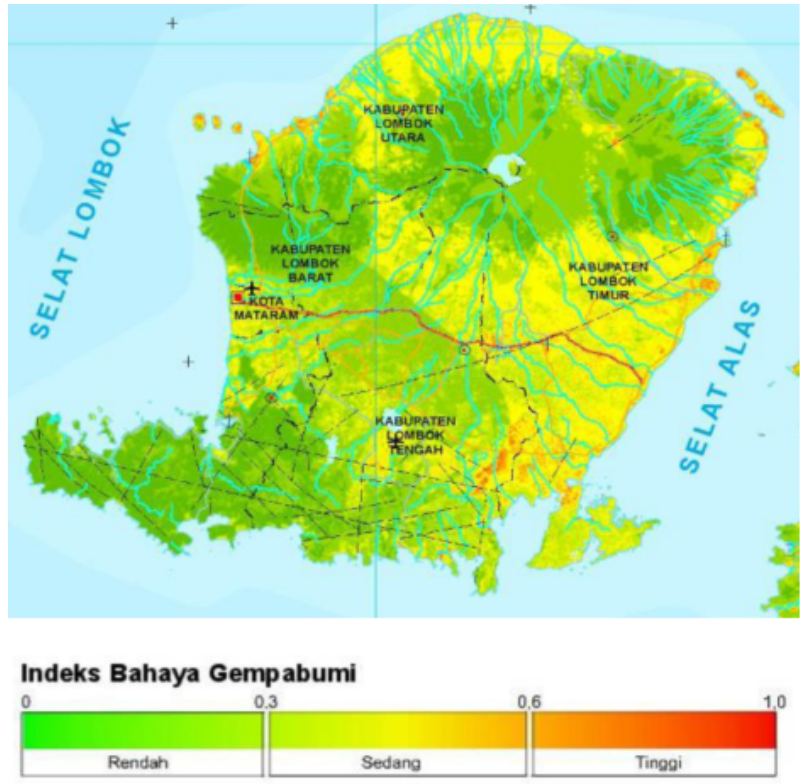

(a)
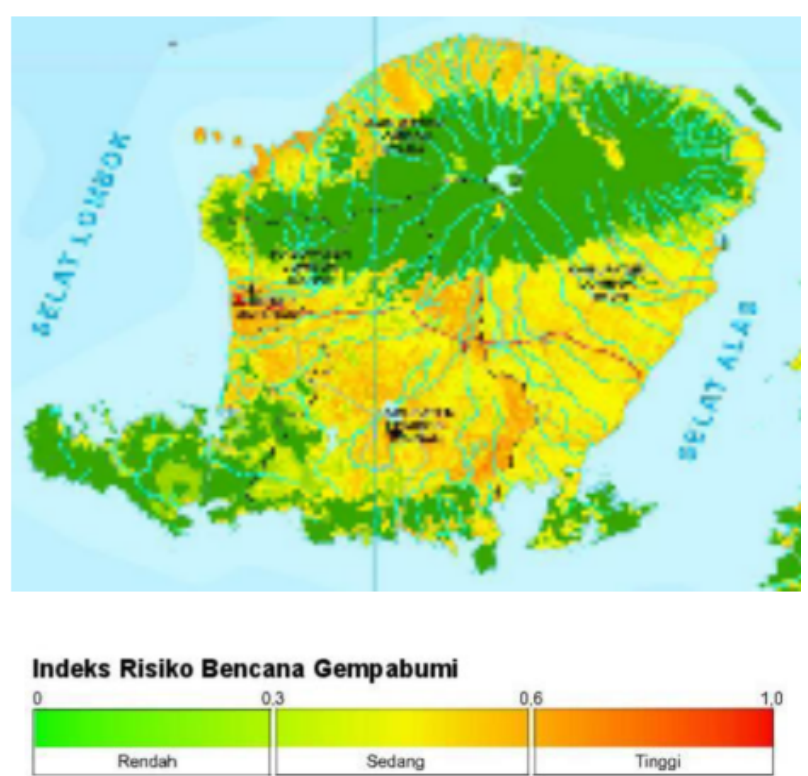

(b)

Gambar 1: Peta bahaya dan resiko bencana gempa bumi wilayah pulau Lombak berdasarkan katalog USGS dan BMKG (warnanya menentukan tingkat bahaya gempa bumi disetiap Kabupaten).

\section{HASIL DAN PEMBAHASAN}

\section{Klasifikasi tingkat bahaya dan resiko gempa bumi di Pulau Lombok}

Sebelum terjadi gempa bumi 2018, Pulau Lombok berada pada daerah rawan gempa. Beberapa puluh tahun lalu, Pulau Lombok sudah sering mengalami gempa bumi dengan magnitude besar dan mengakibatkan beberapa daerah mengalami kerusakan yang sangat parah. Hasil klasifikasi tingkat bahaya gempa bumi selanjutnya dipetakan menjadi peta bahaya gempa bumi di Pulau Lombok seperti pada Gambar 1. Gambar 1 menunjukkan bahwa Pulau Lombok berada didaerah sangat rawan terjadi gempa bumi dan kerusakan bangunan yang diakibatkan oleh getaran gempa. Warna dari setiap wilayah menunjukkan bahwa daerah tersebut menandakan sangat tinggi resikonya. Kerusakan yang terjadi bervariasi sesuai dengan tingkatan masing-masing, sehingga diperlukan perencanaan yang baik untuk menghindari terjadinya kerusakan maupun korban jiwa [11].

\section{Nilai PGA dengan menggunakan metode Donovan}

Nilai PGA di wilayah Pulau Lombok yang dihasilkan hypocenter gempa bumi Lat: -8,390; Long: 116,480; kedalaman $28 \mathrm{~km}$ dan magnitudo sebesar 7,0 SR menggunakan metode Donovan ditunjukkan pada Gambar 2. Gambar ini mengindikasikan adanya perubahan warna dari cokelat sampai dengan hijua tua (dari PGA rendah ke yang lebih tinggi). Wilayah yang memiliki nilai PGA tertinggi yaitu 0,11161 gal yang terdapat di wilayah kabupaten Lombok Utara. Sedangkan nilai PGA terendah yaitu sekitar 0,11021 gal yang terdapat pada wilayah Lombok bagian selatan [4].

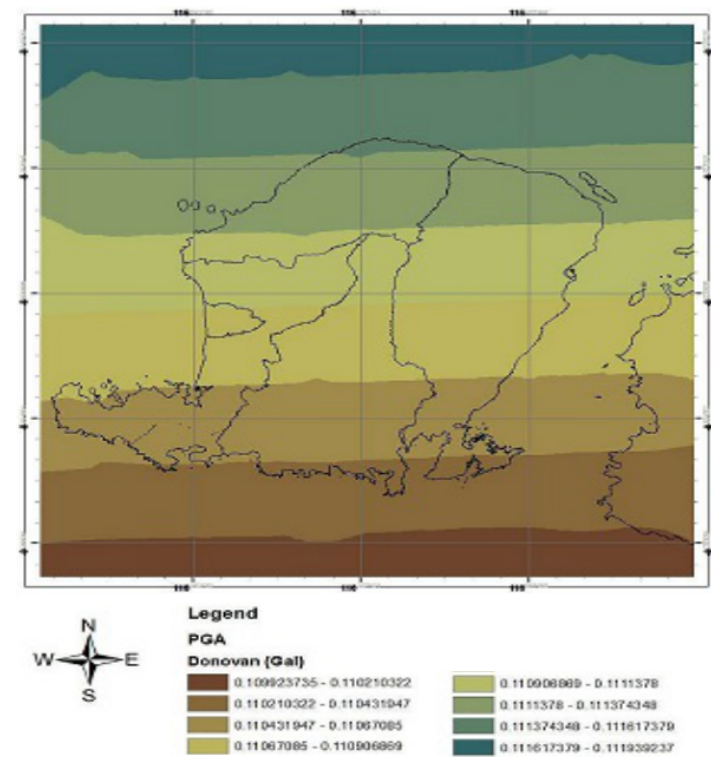

Gambar 2: Peta kontur percepatan tanah maksimum menggunakan rumusan Donovan dengan event gempa bumi 05 Agustus 2018 magnitudo 7,0 SR.

\section{Nilai PGA dengan menggunakan pendekatan Guirre}

Hasil persebaran nilai PGA berdasarkan persamaan Guirre dapat dilihat pada Gambar 3. Gambar 3 mengindikasikan bahwa nilai PGA berkisar antara 0,03441 gal - 0,03503 gal. Nilai PGA tertinggi berada daerah Lombok Utara dan Lombok bagian Barat Laut. Nilai PGA yang tinggi dikedua wilayah tersebut merupakan kontribusi dari gempa bumi Lom- 

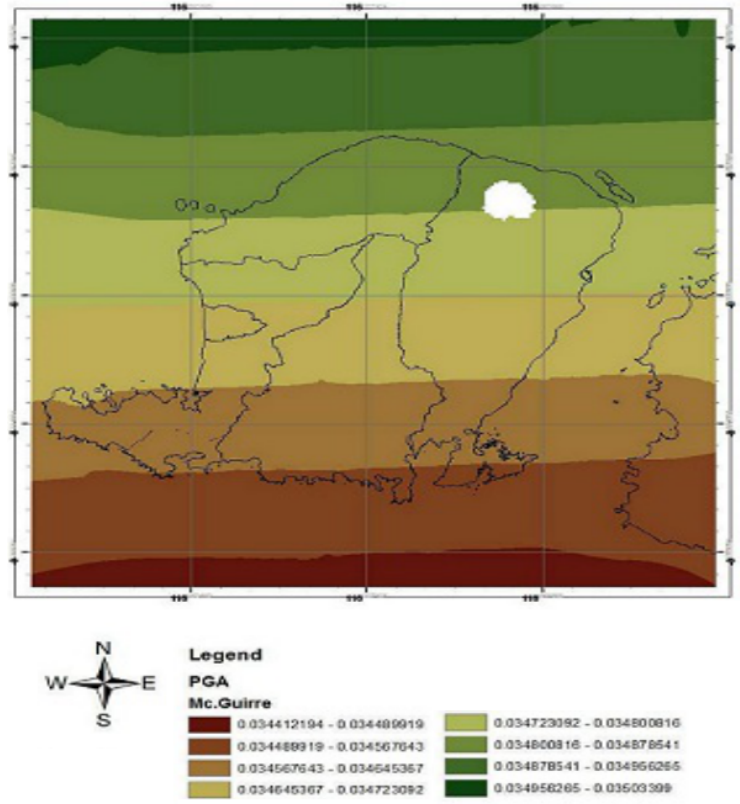

Gambar 3: Peta kontur percepatan tanah maksimum menggunakan rumusan Mc. Guirre dengan event gempa bumi 05 Agustus 2018 magnitudo 7,0 SR.

bok yang terjadi pada 05 Agustus 2018 dengan magnitudo 7,0 SR. Perhitungan nilai percapatan tanah maksimum didasarkan pada besar magnitudo dan jarak hiposenternya. Gempa bumi Lombok memberikan konstribusi nilai percepatan tanah maksimum yang sangat besar karena memiliki jarak yang sangat dekat dengan lokasi penelitian dan kedalam gempa yang cukup dangkal [12].

\section{Nilai PGA menggunakan pendekatan Mickey}

Gambar 4 mendemonstrasikan peta PGA yang disebabkan oleh gempa bumi dengan kedalaman $28 \mathrm{~km}$ dan kekuatan gempa 7,0 SR menggunakan pendekatan yang diusulkan oleh Mickey. Akibat dari sumber gempa tersebut nilai PGA maksimum yaitu 0,05365 gal yang berada di daerah Lombok bagian Utara dan Lombok bagian timur laut [13].

Berdasarkan hasil analisis alat accelerograf, stasiun terdekat dengan sumber yaitu di stasiun Meteorologi BIL (MASE) dengan jarak $48 \mathrm{~km}$ dari pusat gempa bumi yang besar nilai percepatan tanah makimum terbesarnya 43.4444 gals atau 0,0443 gal. Peta shakemap gempa bumi Lombok dengan hasil proses otomatis alat perekam menunjukkan dampak dari gempa bumi dapat berupa kerusakan yang sangat parah didaerah yang berdekatan dengan pusat gempa bumi [14].

Akibat dari gempa bumi 2018, Pulau Lombok semakin rentan terhadap bahaya gempa bumi. Sehingga tingkat kerentanan bahaya gempa yang terjadi di Pulau Lombok sangat tinggi. Secara umum nilai kerentanan bahaya gempa selalu bervariasi di setiap wilayah terutama di Pulau Lombok, tingkat kerentanan bahaya gempa yang pertama didaerah Lombok Barat, daerah ini termasuk kategori rendah tingkat kerentanannya dari 0-0,3. Sedangkan untuk daerah Lombok Tengah dan Lombok Timur berada pada rentan 0,3-0,6.

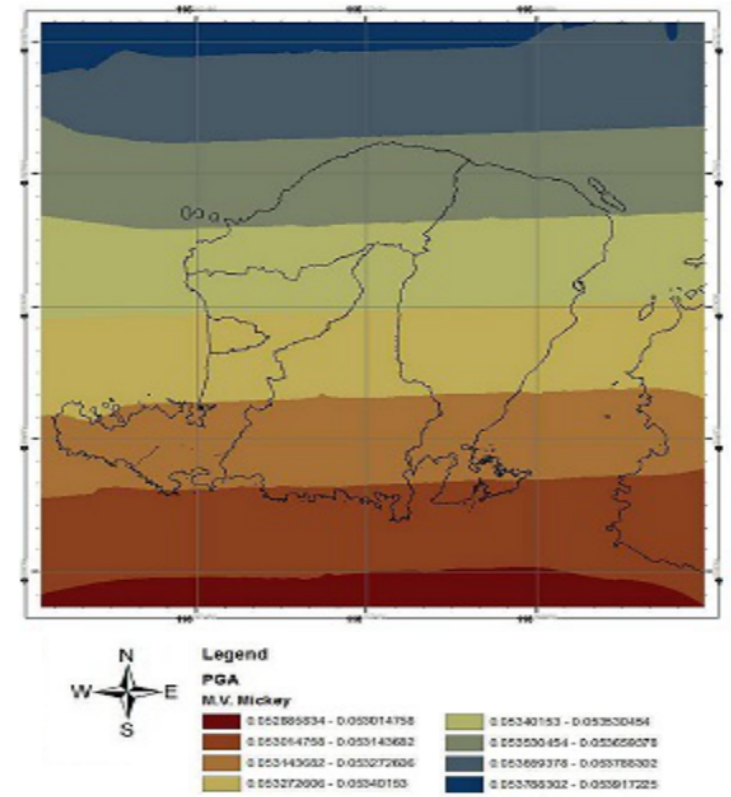

Gambar 4: Peta kontur percepatan tanah maksimum menggunakan rumusan M. V. Mickey dengan event gempa bumi 05 Agustus 2018 magnitudo 7,0 SR

Tingkat kerentanan bahaya gempa paling tinggi berada pada wilayah Lombok Utara dengan besar rentan 0,6-1,0. Semakin tinggi nilai kerentanan gempa di suatu wilayah maka semakin tinggi pula regangan geser tanah yang dialami [15].

Akibat gempa bumi 5 Agustus 2018 dengan magnitudo 7 SR Pulau Lombok memiliki percepatan tanah maksimum yang tinggi, sehingga mengakibatkan banyak kerusakan bangunan yang terjadi. Daerah yang memiliki nilai percepatan tanah maksimum yang relatif tinggi antara lain yang pertama daerah Lombok Utara dan Lombok Timur, yang kedua didaerah kota Mataram dan daerah yang ketiga yaitu daerah Lombok Barat dan Lombok Tengah $[3,16]$.

Selain dari kerentanan bahaya gempa bumi Pulau Lombok juga sangat beresiko terhadap gempa, karena yang mempengaruhi beresikonya wilayah tersebut ada pada kondisi geologi tanahnya. Apabila tanah yang didominasi oleh bebatuan cenderung memiliki tingkat ketahanan lebih tinggi dibandingkan dengan daerah yang bebatuannya lebih sedikit dan faktor jarak antara wilayah tersebut dengan pusat gempa juga sangat mempengaruhi tingkat beresikonya bahaya gempa bumi. Jadi daerah yang sangat beresiko mengalami kerusakan akibat gempa bumi 2018 yaitu daerah Lombok Utara dengan tingkat resiko kerusakan tertinggi berdasarkan penghitungan PGA yaitu 0,1161 gal menggunakan metode Donovan, 0,03441 gal menggunakan metode Guirre dan 0,05365 gal menggunakan metode Mickey. Hal ini disebabkan karena di daerah tersebut kondisi tanah sifatnya berdebu dan ada sedikit celah antara bebatuan, sehingga sangat beresiko tinggi mengalami kerusakan bangunan. Dibandingkan dengan Lombok Tengah, kondisi bebatuan di wilayah tersebut sangat kuat dan padat sehingga resiko kerusakan bangunan akibat gempa tidak terlalu tinggi [17]. 
Kerusakan bangunan juga sering terjadi akibat dari kuatnya guncangan getaran gempa bumi. Hal ini disebabkan karena nilai PGA tidak hanya disebabkan oleh kuatnya getaran gempa melainkan juga dipengaruhi oleh kondisi bebatuan yang ada diwilayah yang terkena gempa. Energi yang berasal dari gempa bumi akan mengalami penguatan energi sehingga kecepatan rotasi batuan akan meningkat dan akan mempengaruhi gerak batuan terutama batuan yang memiliki densitas rendah [18].

Nilai PGA akan semakin meningkat apabila magnitudonya semakin besar, maka getaran yang dihasilkan kepermukaan akan semakin besar dan getaran tanahnya akan semakin kuat, sehingga nilai percepatan tanah maksimum akan meningkat pula. Berdasarkan posisi episenter di zona subduksi nilai percepatan tanah maksimum yang dihasilkan lebih besar. Semakin dekat jarak tiap kota atau kabupaten dengan episenter gempa, maka getaran yang dihasilkan dari gempa bumi akan terasa lebih besar, sehingga nilai percepatan tanah maksimum akan semakin besar pula [19].

Nilai PGA di Lombok Utara menunjukkan bahwa daerah tersebut memiliki tingkat akumulasi tanah endapan sangat tebal sehingga mengakibatkan nilai PGA bernilai tinggi juga. Dengan adanya peta sebaran nilai percepatan tanah dapat diketahui bahwa daerah yang memiliki frekuensi dominan rendah cenderung memiliki tanah endapan yang sangat tebal [20].

Daerah yang memiliki tekstur tanah yang keras biasanya terdapat pada bangunan yang kokoh atau tahan terhadap guncangan gempa, dan jaga tanah yang bertekstur keras getarannya cenderung memiliki frekuensi yang cukup tinggi dan model getaran gelombangnya juga relatif pendek. Begitupun sebaliknya, apabila jenis tanahnya lunak biasanya tidak tahan terhadap guncangan yang terjadi, ini dikarenakan di dalam tanah tersebut terdapat jenis pasir yang halus dan longgar sehingga tidak bisa menahan beban terlalu lama dan mengakibatkan banyak bangunan yang roboh [15].

\section{SIMPULAN}

Persebaran nilai percepatan tanah maksimum yang dihasilkan dari peta Shakemap Pulau Lombok yang diakibatkan oleh gempa bumi zona subduksi dengan kedalaman $28 \mathrm{~km}$ beserta kuat gempa 7.0 SR sebesar 0,0443 gal. Hasil perhitungan percepatan tanah maksimum yang telah dilakukan di Pulau Lombok dengan event gempa 05 Agustus 2018 menggunakan rumusan Donovan relatif lebih tinggi bila dibandingkan dengan rumusan Guirre dan Mickey. Nilai perhitungan rumusan Donovan tertinggi berada di wilayah Pulau Lombok bagian utara dengan nilai percepatan tanah maksimum 0,11161 gal. Rumusan Guirre memiliki nilai tertinggi sebesar 0,03487 gal berada di daerah Pulau Lombok bagian utara, dan rumusan Mickey nilai yang relatif tingggi sebesar 0,05365 berada di wilyah Pulau Lombok bagian utara juga. Dari hasil perhitungan menggunakan rumusan empiris dan hasil dari Shakemap diperoleh bahwa metode pendekatan empiris yang mendekati nilai percepatan tanah maksimum dari Shakemap adalah pendekatan empiris Guirre.

\section{Ucapan Terima Kasih}

Penulis menyampaikan rasa terima kasih kepada BMKG Geofisika Cabang Mataram karena telah mengizinkan penulis untuk melaksanakan penelitian di sana.
[1] S. Cecep, "Deformasi Pulau Lombok Berdasarkan Data GPS", JLBG, vol. 10, no. 1, hlm. 11-18, , April 2019.

[2] A. Sungkowo, "Perhitungan Nilai Percepatan Tanah Maksimum Berdasar Rekaman Sinyal Accelerograph di Stasiun Pengukuran UNSO Surakarta", Apllied Physycs, vol. 8, no. 1, hlm. 43, April 2018.

[3] M.H. Pradono, "Kajian Kerentanan Bangunan Pasca Gempa Lombok 5 Agustus 2018”, BMKG, vol. 2, no. 2, hlm. 19, Juli 2018.

[4] Rahmat, $d k k$., "Analisis Tingkat Kerentanan Seismik di Sumatera Barat Berdasarkan Nilai Percepatan Tanah Maksimum dan Intensitas Maksimum”, Fillar Of Physics, vol. 11, no. 2, hlm. 17-24, Oktober 2018.

[5] H. Yunita, dan R.P. Munirwan, "Kajian Potensi Likuifaksi Akibat Gempa Berdasarkan Data SPT-N di Wilayah Provinsi Aceh", Prosiding Simpisuim II-UNNID.September 2017, hlm. 978-979, 2017.

[6] Z. Netrisa, "Pemetaan Bahaya Gempa Bumi Deterministik dengan Pendekatan Peak Ground Acceleration (PGA) di Kota Padang”, Pillar Of Physic, vol. 11, no. 2, hlm. 41-48, Oktober 2018.

[7] A.D. Chandra, "Relokasi Gempa Utama dan Susulan Mentawai
7,8 Mw dan Implikasinya terhadap Seismotektonik Sumatra", Jurnal Fisika dan Aplikasinya, vol. 11, no. 2, hlm. 64-67, Juni 2015.

[8] E. Ulfiana, "Analisis Pendekatan Empiris PGA (Peak Ground Acceleration) Pulau Bali Menggunakan Metode Donovan, Mc. Guirre, M.V. Mickey”, Ilmu dan Inovasi, vol. 2, no. 2, hlm. 8793, November 2018.

[9] G. Pasau, "Model Percepatan Tanah Maksimum Di Kota Manado", Mifa Unsrat. vol. 7, no. 1, 2018,hlm. 52-55.

[10] D. Pujiastuti dan R. Billyanto, "Analisis Percepatan Tanah Maksimum Wilayah Sumatera Barat(Studi Kasus Gempa Bumi 8 Maret 1977 dan 11 September 2014)", Fisika Unand. vol. 5 , no. 1, Januari 2016, hlm. 53-58.

[11] A. Hamidi, $d k k$., "Analisis Korelasi Displacement dan Acceleration Dengan Nilai PGA Menggunakan Metode Dinamik Respon Spektrum Pada Tanah Lunak di Riau”, Santek, vol. 4, no. 2, Tahun 2016.

[12] R. Hafid, dkk., "Percepatan Tanah Berdasarkan Data Mikroseismik Wisata Bantir Sumowono Semarang", Unnes Physics, vol. 6,no. 1, Desember 2017.

[13] U.N. Prabowo, dan Ayu F. Amalia, "Analisis Percepata Getaran Tanah Maksimum Untuk Memetakan Resiko Bencana Gempa 
Bumi di Kabupaten Pemalang Jawa Tengah", Science Tech, vol. 4, no. 2, Agustus 2018

[14] M.R. Syofyan, dan H. Edial, "Estimasi Percepatan Tanah Maksimum dan Intensitas Gempa di Kota Padang Berdasarkan Skenario Gempa Bumi di Megathrust Mentawai Menggunakan Menggunakan Metode Deterministik”, Buana, vol. 3, no. 1, Tahun 2019.

[15] F. Anggriani, dkk., "Analisa Komparatif Percepatan Tanah Maksimum Akibat Gempa Bumi M6.3 di Selat Mentawai Berdasarkan Rumusan Empiris Ground Motion Prediction Equation (GMPE)", Physics, vol. 11, no. 1, hlm. 49-53, Maret 2018.

[16] A. Yudi, dkk., "Ulusan Guncangan Tanah Akibat Gempa Lombok Timur 05 Agustus 2018", BMKG, Tahun 2018

[17] B. Sunardi, dkk., "Estimasi Percepatan Tanah Maksimum dan Spektra Percepatan Akibat Gempa 7 Desember 2016 di Kabu- paten Pidie Jaya", Proceeding, Seminar Nasional Kebumian ke10, Yogyakarta, September 2017.

[18] A. Putri, dkk., "Identifikasi Percepatan Tanah Maksimum (PGA) dan Kerentanan Tanah Mennggunakan Metode Mekrotremor I Jalur Sesar Kendeng”, Geosaintek, vol. 3, no. 2, hlm. 107-114, 2017.

[19] D. Syafriana, dkk., "Estimasi Nilai Percepatan Tanah Maksimum di Sumatera Barat Berdasarkan Skenario Gempa Bumi di Wilayah Siberut Dengan Menggunakan Rumusan Si And Midorikawa (1999)", Fisika Unnad, vol. 4, no. 4, hlm. 365-374, Desember 2015.

[20] M.F.N. Putra, dkk., "Analisis Site Effect Berdasarkan Data Mikrotremor dan Nilai Peak Ground Acceleration pada Sesar Opak Kabupaten Bantul Daerah Istimewa Yogyakarta", Geofisika Eksplorasi, vol. 3, no. 3, hlm. 99-115, 2015. 